\title{
Spotted hyaenas and the sexual spectrum: reproductive endocrinology and development
}

\author{
Alan Conley ${ }^{1}$, Ned J Place², Erin L Legacki ${ }^{1, \dagger}$, Geoff L Hammond ${ }^{3}$, Gerald R Cunha ${ }^{4}$, Christine M Drea5, \\ Mary L Weldele ${ }^{6}$ and Steve E Glickman' ${ }^{6}$ \\ 1Department of Population Health \& Reproduction, School of Veterinary Medicine, University of California, Davis, California, USA \\ 2Department of Population Medicine and Diagnostic Sciences, College of Veterinary Medicine, Cornell University, Ithaca, New York, USA \\ ${ }^{3}$ Department of Cellular \& Physiological Sciences, University of British Columbia, Vancouver, British Columbia, Canada \\ ${ }^{4}$ Department of Urology, University of California, San Francisco, California, USA \\ ${ }^{5}$ Departments of Evolutionary Anthropology and Biology, Duke University, Durham, North Carolina, USA \\ ${ }^{6}$ Departments of Psychology and Integrative Biology, University of California, Berkeley, California, USA
}

Correspondence should be addressed to A Conley: ajconley@ucdavis.edu

${ }^{\dagger}($ E L Legacki is now at National Institute of Standards and Technology, Hollings Marine Laboratory, Charleston, South Carolina, USA)

\begin{abstract}
The spotted hyaena (Crocuta crocuta) is a unique species, even amongst the Hyaenidae. Extreme clitoral development in female spotted hyaenas challenges aspects of the accepted framework of sexual differentiation and reproductive function. They lack a vulva and instead urinate, copulate and give birth through a single, long urogenital canal that traverses a clitoris superficially resembling a penis. Recent and historical evidence is reviewed to describe our changing understanding of the biology of this species. Expanding upon observations from hyaenas in nature, much has been learned from studies utilising the captive colony at the University of California, Berkeley. The steroid environment of pregnancy is shaped by placental androgen and oestrogen secretion and a late gestational increase in sex hormone binding globulin, the regulated expression and steroid-binding characteristics of which are unique within the Hyaenidae. While initial external genital development is largely free of androgenic influence, the increase in testosterone concentrations in late gestation influences foetal development. Specifically, anti-androgen (AA) treatment of pregnant females reduced the developmental influence of androgens on their foetuses, resulting in reduced androstenedione concentrations in young females and easier birth through a 'feminised' clitoris, but precluded intromission and mating by 'feminised' male offspring, and altered social interactions. Insight into the costs and benefits of androgen exposure on spotted hyaena reproductive development, endocrinology and behaviour emphasises the delicate balance that sustains reproductive success, forces a re-evaluation of how we define masculine vs feminine sexual characteristics, and motivates reflection about the representative value of model species.
\end{abstract}
Key Words
- sexual differentiation
- hyaena/hyena
- endocrinology
- differentiation
- androgen 


\section{Journal of Endocrinology}

\section{Introduction}

Mammalian external genitalia are not always distinctly sexually dimorphic (Glickman et al. 2005) but the female spotted hyaena (Crocuta crocuta) is unique in the degree to which her genitalia resemble those of the male in form and even some functional aspects. Females of this species lack a vaginal opening in the perineal region, having instead a urogenital canal traversing a clitoris (similar in size to the penis) through which they urinate, copulate and give birth (Watson 1877, Matthews 1939). Female elephants also have a long urogenital canal (Perry 1964, Balke et al. 1988) and a well-developed clitoris which is difficult to differentiate grossly from the flaccid penis of the bull elephant (Perry 1964, Glickman et al. 2005). Especially when flaccid, the distinction between the clitoris and the penis in terms of size, shape and position (Fig. 1) is also minimal in spotted hyaenas (Matthews 1939, Neaves et al. 1980, Frank et al. 1990, Drea et al. 1998, Cunha et al. 2003, 2005, 2014, 2020). But, what makes the clitoris of the spotted hyaena so clearly unique is the degree of erectile tissue development, the functional significance of erection in both sexes when conspecifics greet one another (Hamilton III et al. 1986, East et al. 1993), and the difficulty (to an untrained eye) in distinguishing the clitoris from the penis in the erect state. Copulation is not an easy process in this species (Drea et al. 2018); the clitoris of the spotted hyaena must remain flaccid when the male is aroused and the penis is erect. Retractor clitoral muscles draw the clitoral meatus backwards to facilitate intromission made difficult by its rostral location (Neaves et al. 1980). Hence, the clitoris of the spotted hyaena has been variously described as 'peniform', 'phallic', 'masculinised' or 'virilised', the genitalia in general as 'hermaphroditic' (Glickman 1995), and the species has been seen to exemplify 'female deviance from gender norms' (Wilson 2003). Spotted hyaenas have thus fascinated biologists in the degree to which they deviate from a binary view of sexual dimorphism in mammals, exhibiting a behavioural repertoire (including pronounced aggression, social dominance, territorial leadership, glandular scent marking and rough play) that emphatically challenges the commonly perceived norms of male dominance. Accordingly, time-sensitive, androgen-dependent mechanisms that most commonly direct the development of a penis and scrotal sac (George \& Wilson 1994, Griffin et al. 2001), as well as later, sexually differentiated behaviours (Phoenix et al. 1959), have been explored in efforts to explain the genesis of the external genitalia of the female spotted hyaena.

(c) 2020 Society for Endocrinology Published by Bioscientifica Ltd. Printed in Great Britain

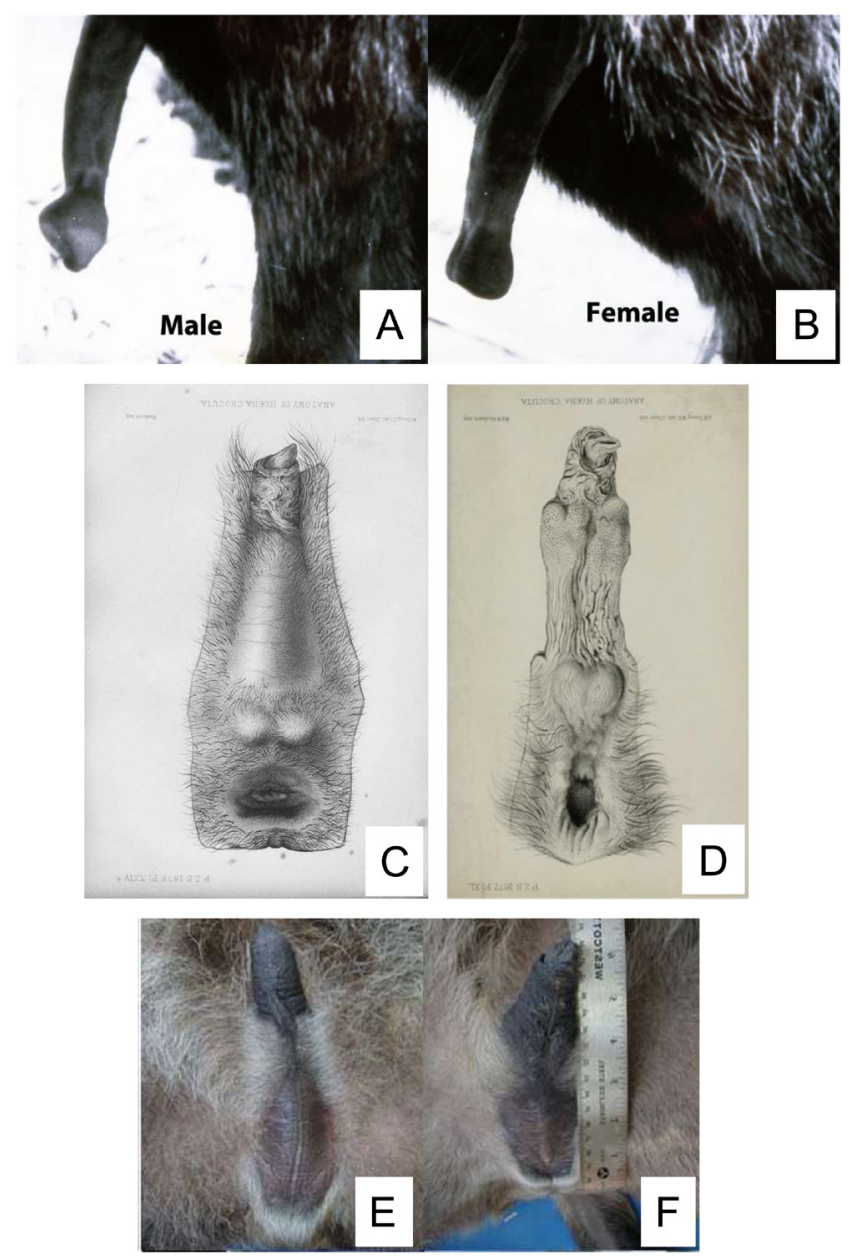

Figure 1

The gross anatomy of the male and female genitalia of the spotted hyaena (Crocuta crocuta). Shown are the penis (A) and clitoris (B) in the erect state. The external genitalia of a male (C) and female (D) as illustrated in the flaccid state by Watson $(1877,1878)$ showing the similarity in position and size of the clitoris compared with the penis, as well as the pseudoscrotum and lack of a vulvar opening in the female perineum. Also shown are photographic images of the male (E) and female (F) genitalia side by side. Note again, the lack of a vulva in the perineal region of the female.

\section{Scientific and social context}

Not surprisingly, the reproductive biology of the spotted hyaena has attracted attention from traditional biological (Glickman et al. 1992a) and evolutionary (Gould 1983) perspectives. However, researchers studying a species as unusual as the spotted hyaena can face significant challenges in obtaining federal funding which can require justification in terms of human relevance (Blaschko et al. 2012). This may have biased the way in which the biology of spotted hyaenas has sometimes been portrayed, used and perhaps even misused symbolically, drawing undue scrutiny in non-biological disciplines or social contexts 
(Wilson 2003, Bewell 2014, Szczygielska 2017). Ironically, L Harrison Matthews, whose classic monograph (Matthews 1939) fuelled so much subsequent research on spotted hyaenas, 'objected strongly to anthropomorphism in any kind' (Matthews 1987). Funding imperatives might also explain discussions of the spotted hyaena as a 'model' for other species when in fact its real value perhaps lies in being the exception that tests/challenges so many biological rules, exposing the narrow vision that drives much 'model' research (Beach 1950). As proposed in an earlier review article, 'we hoped that through the use of an unusual female mammal we would challenge the adequacy of current understanding of the process of sexual differentiation' (Glickman et al. 1992a) which, indeed, it has. The following review will provide an update of the state of knowledge of the reproductive endocrinology in spotted hyaenas during foetal development as well as in post-natal life. References to other mammals have been utilised only to better appreciate what sets this species apart from all others, even those among the Hyaenidae (Drea et al. 2018), and to illustrate the breadth of variation in mechanisms and outcomes of mammalian sexual differentiation and reproductive function.

\section{Sexual development and genital differentiation}

A discussion of the reproductive endocrinology of the spotted hyaena must, by necessity, begin with a description of their sexual development which has drawn so much interest and attention over millennia (Glickman 1995). The predominant view of mammalian sexual differentiation is grounded largely on the pioneering experiments by Alfred Jost, who surgically removed and then transplanted gonads between foetal rabbits and observed the consequences with respect to subsequent development of the male and female reproductive tracts after the gonads had differentiated (Jost 1948, Jost et al. 1973). Based on these studies it was concluded that development of the male genitalia is directed by testicular hormonal secretions in early foetal life, and that the female habitus forms 'by default' in the absence of testicular endocrine influence (Jost et al. 1973, Jost 1991). This basic foundation was later extended to the neural structures underlying sexual differentiation of behaviour (Phoenix et al. 1959) and has been shaped and reinforced extensively by observed variations in human, macaque and rodent sexual development (Goy et al. 1988, Cunha et al. 2020), that have been traced to specific genes and their products (Wilson et al. 1981, George \& Wilson 1994, Gustafson \& Donahoe 1994, Sobel et al. 2004, Rey \& Grinspon 2011). The extent to which other species conform to this paradigm has received limited attention by comparison (Cunha et al. 2020).

The results of studies in pre- and post-natal spotted hyaenas indicated that 'masculinisation' of their genitalia is not as strictly androgen-dependent (Drea et al. 1998, Cunha et al. 2020) as it is in other mammalian species (Herman et al. 2000). In their recent review of sexual differentiation in the spotted hyaena, Cunha et al. noted that penile length at 2 years of age was similar in hyaenas castrated as cubs compared with those left intact, suggesting that post-natal penile development is largely androgen-independent (Glickman et al. 1992b, Cunha et al. 2014). Likewise, clitoral length at 2 years of age was minimally affected by ovariectomy of immature cubs. Moreover, prenatal penile and clitoral development also appears initially to be relatively androgen-independent, though androgens influence subsequent differentiation. For example, the embryonic genital tubercle is already prominent (Lindeque \& Skinner 1982), and the basic form of the phallus is determined in both males and females (Cunha et al. 2014), long before the foetal gonads become capable of androgen synthesis (Browne et al. 2006).

As grossly similar as clitoral and penile morphology might be in spotted hyaenas, there are additional dimorphic features that differentiate in response to androgen stimulation in male foetuses. The penile urethra has a slit-like lumen and is surrounded by the corpus spongiosum and the tunica albuginea, whereas the clitoris has a large voluminous pleated 'urethra' the expansion of which is required for receipt of the penis during mating and to facilitate foetal delivery at parturition. Androgendependent developmental processes in male foetuses are necessary for generating the basic architecture required for successful reproduction and these include: (1) formation of the prostate, (2) ventral positioning of the retractor muscles relative to the urethra, (3) a small urethral lumen, (4) development of a thick tunica albuginea surrounding the corporal body, (5) formation of the corpus spongiosum surrounding the urethra, and (6) the form and position of erectile bodies in the glans that on erection determine the chisel-shaped tip required for successful mating (Cunha et al. 2014) (Supplementary Table 1, see section on supplementary materials given at the end of this article). Thus (and in contrast to the female), androgenic stimulation has an important influence on genital development in the male spotted hyaena. 


\section{Early evidence for androgens and female genital masculinisation}

The idea that genital development in female spotted hyaenas was 'masculinised' by androgen exposure in utero derived, in part, from the perceived extreme masculine appearance of the female external genitalia (clitoral hypertrophy and labial fusion) and, in part, from the accompanying suite of additional traits traditionally viewed as 'masculine'. These include a reversal of sexual size dimorphism (i.e. female hyaenas are generally larger than males (Swanson et al. 2013, Drea et al. 2018)) as well as behavioural traits more routinely displayed by male mammals than by their female counterparts such as aggression and social dominance (Frank 1986), leadership in territorial defence (Boydston et al. 2001), pronounced scent marking (Henschel \& Skinner 1991) and rough play (Pedersen et al. 1990), often associated with androgen influence. Given this composite picture, the search for a source of androgens in females initially directed much of the research.

The foundational endocrine studies relied on field specimens, using estimated ages (especially of foetuses), presumed maturity, and relatively basic analytical methods. Hence, Racey \& Skinner (1979) used direct immunoassays to measure androgens (testosterone and androstenedione) and other steroids (progesterone, oestrone and oestradiol) in adult spotted hyaenas (parous, non-parous, lactating), as well as in adult brown (Parahyaena brunnea) and striped hyaenas (Hyaena hyaena). Initially, they suggested that males could not be discerned from female spotted hyaenas based on steroid concentrations in single serum samples, even though ovarian tissue contained less testosterone than did the testes or adrenal glands, the latter being considered another possible tissue source of androgens (Racey \& Skinner 1979). In contrast, male brown and striped hyaenas had higher circulating testosterone concentrations than did females of those species. In addition, a single pregnant spotted hyaena female carrying twin female foetuses was investigated and testosterone concentrations were found to be within a similar range in maternal and foetal serum seemingly supporting the idea that female 'virilisation' in this species occurred in utero (Racey \& Skinner 1979).

Androgen concentrations were explored further in another four pregnancies bearing mixed-sex twins that were sampled for direct immunoassay of androgens organically extracted from maternal or foetal plasma and tissue. Testosterone concentrations in maternal plasma at an estimated $31,65,75$ and 80 days of gestation (based on hypothetical foetal growth velocity and duration of gestation) (Huggett \& Widdas 1951, Frazer \& Huggett 1974), were 0.98, 0.03, 0.63 and $3.60 \mathrm{ng} / \mathrm{mL}$, respectively, the last value representing almost an order of magnitude increase (Lindeque \& Skinner 1982). Maternal androstenedione concentrations were 2.6, 26.2 and $5.2 \mathrm{ng} / \mathrm{mL}$ on days 65,75 and 80 , respectively (Lindeque \& Skinner 1982), consistently higher than had been previously reported (Racey \& Skinner 1979). The highest plasma concentrations of testosterone were found in twin 31-day-old foetuses, at least twice as high as in any of the male or female foetuses at older ages. However, the defined sex of that foetus was based on 'phallic' size, which was assumed to be larger in males even at this early stage (Lindeque \& Skinner 1982). Direct comparisons of foetal plasma androgen concentrations were made in mixed-sex twins at 65 and 80 days of gestation. Testosterone was slightly higher in the male than in the female co-twin at both gestational ages, but androstenedione concentrations were almost the same. Therefore, the authors concluded, '...that masculinisation of the genital tubercle of female spotted hyaena foetuses results, as in the male, from an episode of androgen secretion by the foetal gonad' (Lindeque \& Skinner 1982).

A potential contribution of the ovaries and adrenal glands to circulating androgen concentrations was investigated in samples from juvenile, sub-adult and adult males and females (Lindeque et al. 1986). Females were classified by reproductive state as nulliparous or as parous and non-pregnant, pregnant and lactating, and gonadal response to human chorionic gonadotropin (hCG) and gonadotrophic releasing hormone (GnRH) was also assessed. Sub-adult males had lower androstenedione concentrations than females, and concentrations of both testosterone and androstenedione were higher in pregnant than non-pregnant females. Both testosterone and androstenedione were elevated after stimulation with hCG; however, a similar increase after adrenocorticotropic hormone stimulation suggested some adrenal contribution was possible (Lindeque et al. 1986). This finding was consistent with the earlier observation that androgen concentrations in adrenal tissue of adult females were considerably higher than those in the ovary (Racey \& Skinner 1979). Ultimately, however, it was concluded that the ovary was the principal source of the unusually high, circulating concentrations of androstenedione observed in the non-pregnant female spotted hyaena (Lindeque et al. 1986).

Lastly, androgen concentrations in male and female spotted hyaenas were investigated once again, but in a 
larger cohort of subjects of varying ages from cubs to adults stratified into social categories for each sex (van Jaarsveld \& Skinner 1991). Non-parous females had higher androstenedione concentrations than mature and immature males, as did female cubs relative to male cubs; however parous females had higher testosterone concentrations than did immature males (van Jaarsveld \& Skinner 1991). This was confirmed subsequently by faecal androgen analysis (Dloniak et al. 2006a) showing that socially central and integrated, immigrant males had higher plasma testosterone and faecal androgen concentrations than did adult natal males or pregnant females which did not differ from one another (Dloniak et al. 2004).

Collectively, the data from these early studies indicated that the differences in androgen concentrations between male and female spotted hyaenas were complex, dependent on age, residency, social status and female reproductive state. With respect to apparent female 'masculinisation', the broad conclusion from this early work was a tacit reaffirmation of Jost's dictum in terms of foetal gonadal androgens (androstenedione in this case) influencing genital differentiation. However, one observation also cast doubt on this interpretation. Lindeque and Skinner noted that despite apparent 'masculine' development of the external genitalia of the female foetuses, there was no stabilisation of the Wolffian ducts (Lindeque \& Skinner 1982), which is another, well-recognised androgen response (Jost 1970, Schultz \& Wilson 1974, George \& Wilson 1994, Shaw $\&$ Renfree 2014). The Wolffian ducts had regressed in these female hyaena foetuses by what was estimated to be 80 days of gestation, despite apparent 'virilisation' of their external genitalia (Lindeque \& Skinner 1982). Indeed, the possibility that the broader architecture of genital differentiation in the female spotted hyaena foetus might not rely solely on androgen exposure has been borne out in studies conducted since that time. For instance, it has become clear that the foetal ages in those early field studies were grossly underestimated. A foetus at 31 days of gestation cannot be sexed anatomically, too little blood can be recovered for analysis at this stage and the conclusions drawn with respect to androgenic effects on female development have proven to be incorrect (Browne et al. 2006, Cunha et al. 2014). More precise understanding of the timing of prenatal events has been key to advancing our understanding of spotted hyaena sexual differentiation.

\section{Contributions from the Berkeley Hyaena Colony}

In the mid-1980s, a captive colony of spotted hyaenas was established at University of California, Berkeley to better examine the premise of maternally acquired 'sexual mimicry' in genital anatomy, endocrinology and behaviour that eventually challenged aspects of Jost's framework (Cunha et al. 2014). This facility enabled protocols that were virtually impossible or otherwise lethal in the field and experiments that could be planned with more precisely timed, strategic sampling points, both pre- and post-natally (Glickman et al. 1987, 1992b, Frank et al. 1991). Captive animals were socially housed in mixed-sex groups, had access to outdoor enclosures and so experienced natural light cycles and temperatures, received an obligate carnivore diet that included unprocessed meats and bones, and could be observed at any time of the day or night, across the life span from the time of birth. This facilitated longitudinal blood sampling of live pregnant and neonatal animals, for example, showing that testosterone concentrations were very high in pregnant females (Licht et al. 1992) and were consistently higher in male than female neonates (Frank et al. 1991), but that androstenedione concentrations were similar in neonates of both sexes, as previously reported (Lindeque \& Skinner 1982). The reversal of the sex difference in androgen concentrations was confirmed and extended by Glickman et al. (1987) who later included chromatography as part of assay validation (Glickman et al. 1992b). They demonstrated that the elevation of androstenedione was more pronounced in juvenile than in mature females and that the ovaries were the principal source (Glickman et al. 1987, 1992b). Tissues also became available for more extensive in vitro analysis. In fact, the capacity for androgen production by the ovary of the spotted hyaena is considerable. The rate of androgen synthesis by ovarian tissue, measured using a radiometric method (Moran et al. 2002), was higher than that of the testes or adrenal gland $(13.4 \pm 0.5,11.2 \pm 0.2$ and $8.2 \pm 1.0 \mathrm{nmol} / \mathrm{mg} / \mathrm{h}$ in ovarian, testicular and adrenal tissue homogenates, respectively).

Access to a captive colony made larger-scale, comprehensive and longitudinal analysis of steroid concentrations in maternal plasma during pregnancy possible (Licht et al. 1992). Surgeries could also be planned in females known to be pregnant. Thereby, plasma was sampled from various maternal and foetal https://joe.bioscientifica.com https://doi.org/10.1530/JOE-20-0252 (c) 2020 Society for Endocrinology Published by Bioscientifica Ltd. Printed in Great Britain 
blood vessels to investigate veno-arterial differences within and across the uterus at days 90 and 96 of gestation. Examination of progesterone, androstenedione, testosterone and oestrogen was conducted by immunoassays validated in part by chromatography on pooled samples. Several important observations were made suggesting that progesterone, testosterone and oestrogen, the concentrations of which increased progressively during pregnancy (Licht et al. 1992), were synthesised by the placenta. First, progesterone concentrations were higher in pregnant than non-pregnant females. Second, progesterone concentrations progressively increased as pregnancy proceeded, as did testosterone and oestrogen, whereas androstenedione concentrations ( $>6 \mathrm{ng} / \mathrm{mL}$ ), remained relatively constant. Third, progesterone and testosterone concentrations were higher in uterine venous than systemic plasma. Lastly, concentrations of progesterone, testosterone and oestrogen dropped within hours of placental removal at Caesarian section in two late-stage pregnancies. It was suggested that the placenta synthesised testosterone from circulating androstenedione although their concentrations were not correlated in these studies. The lack of clear difference in testosterone concentrations between male and female twin foetuses, together with higher concentrations in umbilical than foetal jugular vein, was also taken as evidence that maternal testosterone might even contribute to foetal concentrations to some degree (Licht et al. 1992). Subsequent reports of increased faecal and serum testosterone concentrations in pregnant vs non-pregnant females (Dloniak et al. 2004, 2006b), and of progressively increased faecal oestrogen across gestation (Van Meter et al. 2008), are consistent with the longitudinal data from pregnancies in the colony (Licht et al. 1992).

Despite the access provided by a breeding colony, mating was not routinely detected amongst spotted hyaenas (outside of timed pairings) and, therefore, estimates of the stage of gestation as reported often remained approximate (Licht et al. 1992). Still, earlier stages of foetal and placental development were investigated in a subsequent experiment involving Caesarian sections on seven pregnancies estimated to be $33,48,50,58,64,78$ and $>100$ days of gestation, yielding a total of 10 foetuses (Licht et al. 1998). Seminiferous cords were evident in the developing testes of a male foetus at day 50 of gestation, but the ovaries of a 48-dayold foetus were still undifferentiated. In these comparably aged foetuses, Müllerian and Wolffian ducts were present in both sexes, extending all the way to the urogenital sinus. Regression of the Müllerian ducts by anti-Müllerian hormone $(\mathrm{AMH})$ in the male had not begun or was not yet obvious at 50 days of gestation nor was there evidence of Wolffian duct regression in the female foetus. These observations contrasted those of Lindeque and Skinner who reported that Müllerian ducts had regressed at day 50 in a male foetus and the Wolffian ducts of a female foetus of the same age were detectably degenerating (Lindeque \& Skinner 1982). The discrepancy likely reflects the inaccuracy in estimates of foetal age of the field specimens, but suggests that the window of time during which these events transpire might be relatively narrow, occurring sometime after day 50 of gestation.

Gonadal differentiation was examined in more detail in tissues recovered at Caesarian section from colony females from 30 to 95 days of gestation (Browne et al. 2006). Expression of AMH in Sertoli cells and enzymes required for androgen synthesis in Leydig cells were evident even at day 30 in foetal testes, helping to define early development of cords in the testes, a level of organisation not evident in ovaries of the female twin sibling. The ovaries remained generally unorganised anatomically and with little evidence of steroidogenic enzyme expression at gestation day 45 (Fig. 2B). In contrast, the foetal testes were well organised into seminiferous tubules and there was robust expression of enzymes enabling androgen synthesis in the interstitial space (Fig. 2A). By day 65 of gestation, however, the foetal ovaries were organised into distinct medullary and cortical compartments. Moreover, there was a strong expression of steroidogenic enzymes

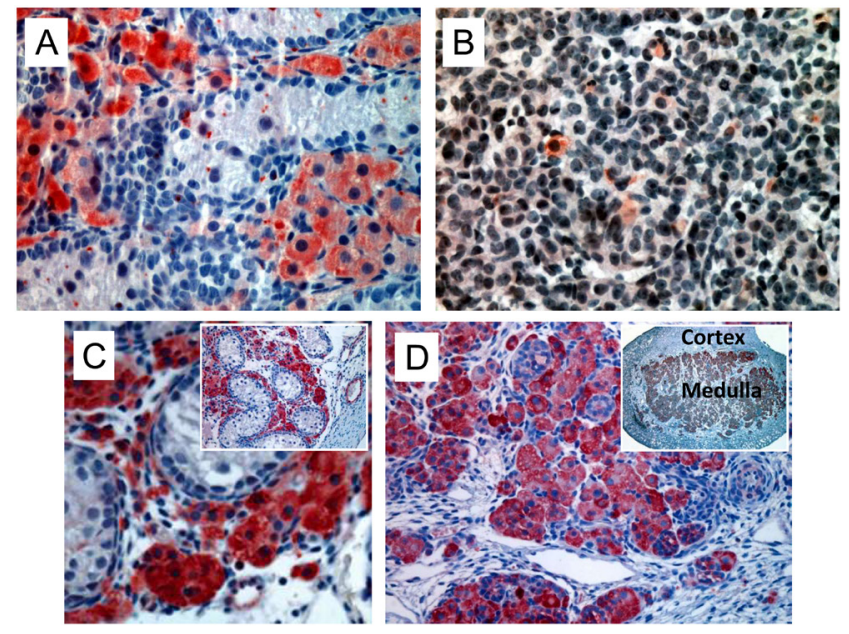

\section{Figure 2}

Histological development of testicular (A and C) and ovarian (B and D) organisation and steroidogenic differentiation, as indicated by immunohistochemically detected the expression of $3 \beta$-hydroxysteroid dehydrogenase (red chromagen), in spotted hyaena foetuses at gestation days 45 ( $A$ and $B$ ) and 65 (C and $D)$. 
catalysing androgen synthesis in the ovarian medullary region (Fig. 2D) that was comparable in intensity to that seen in the Leydig cells in the testes of the male twin (Fig. 2C). The ovarian medullary expression of enzymes required for androgen synthesis was consistent with androstenedione concentrations in the plasma of female foetuses at days 65 and 95 that were similar to those in their male twins, but only the male foetuses had detectable testosterone concentrations (Browne et al. 2006).

Collectively, the evidence obtained suggested that male foetal gonads were capable of androgen secretion at a much earlier stage of development than had previously been thought. In addition, these data suggested that foetal ovarian development and steroidogenic differentiation was delayed relative to the foetal testis, not being evident until day 65 . Thereafter, the apparent capacity for steroidogenesis in the ovarian medulla was robust, consistent with earlier speculations (Matthews 1939, Racey \& Skinner 1979). The proposed time course of these events in the spotted hyaena illustrates the developmental delay in steroidogenic differentiation of foetal ovaries compared with the foetal testes, as summarised (Fig. 3), and argues against a role of foetal androgens in determining gross size with respect to female phallic development.

The steroidogenic potential of the spotted hyaena placenta was also investigated (Yalcinkaya et al. 1993,

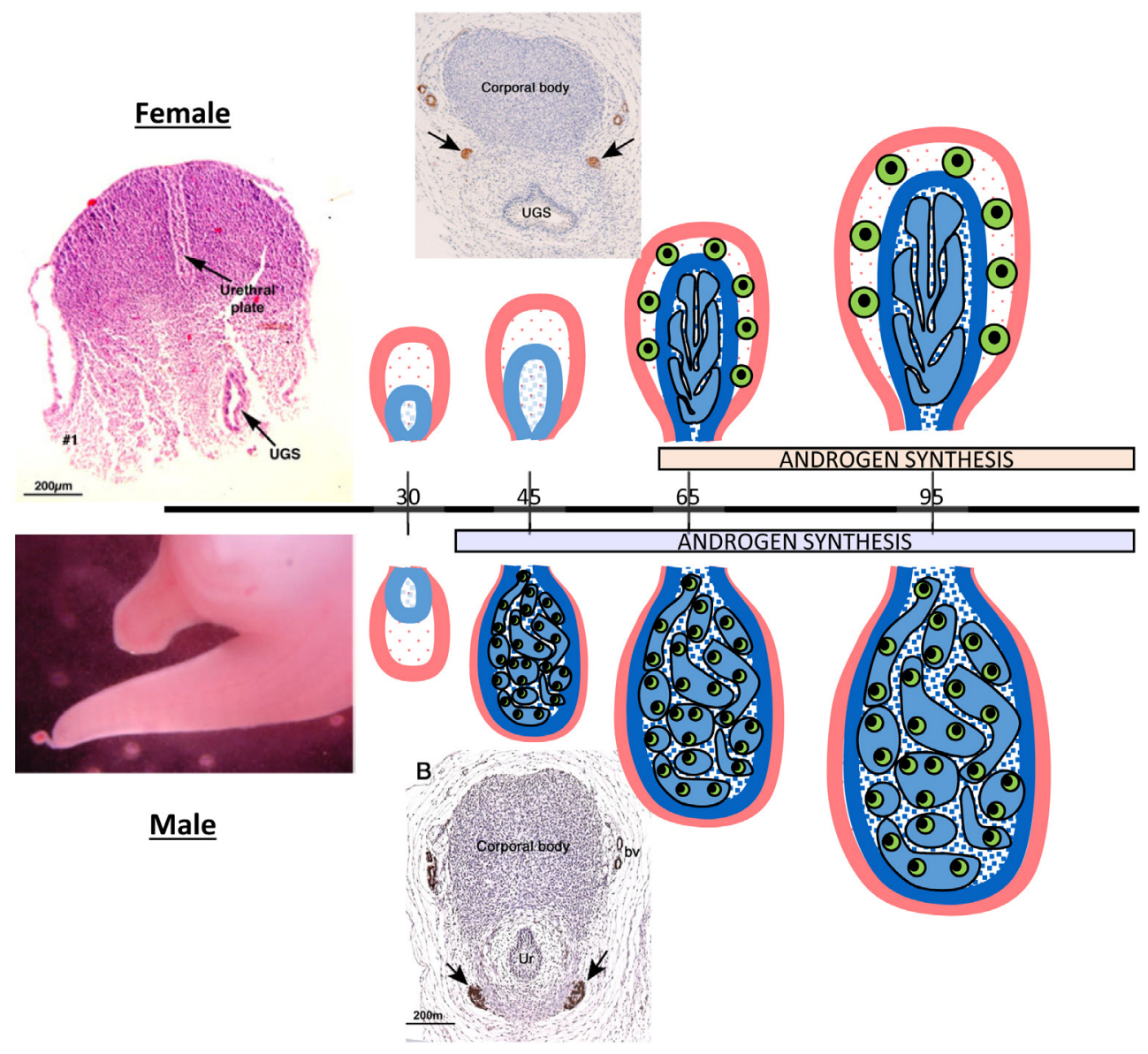

Figure 3

Schematic summary of developmental events involving the gonads and associated reproductive tissues in female (above the timeline) and male (below) spotted hyaena foetuses from days 30 to 95 of gestation (gestation averages 111 days from observed mating to parturition in this colony). The images (left) on the timeline show histology (upper) and gross appearance (lower, with tail beneath) of the genital tubercle in a day 30 foetus at which time there is no differential development in relation to sex. The schematic representation of gonadal development (right) depicts the gonadal cortex in pink, the medulla in blue and germ cells in green. The gonads of both sexes are relatively undifferentiated at day 30 , though some primitive cords and expression of anti-Müllerian hormone were evident in foetal testes (not shown). The foetal testes are well differentiated by day 45 with robust expression of steroidogenic enzymes, but the ovaries were still unorganised and relatively undifferentiated. By day 65 , the ovarian medulla is well organised and exhibits robust expression of steroidogenic enzymes comparable to the testes and consistent with androgen synthesis. Images of histological sections through the clitoris (above) and penis (below) showing the retractor muscles (immuno-positive for smooth muscle actin; arrows) dorsal to the urogenital canal (UGC) in the clitoris but ventral to the UGC in the penis, a response to foetal testicular androgen (see text). 
Licht et al. 1998, Conley et al. 2007), complementing morphological studies clearly defining its hemochorial nature (Enders et al. 2006, 2007), a feature apparently also shared with the striped hyaena (A C Enders, C M Drea \& A Conley, unpublished observations). Licht and colleagues provided evidence of testosterone synthesis by the spotted hyaena placenta based on a positive venoarterial difference across the uterus coincident with a negative veno-arterial difference in androstenedione concentrations. In addition, they demonstrated the conversion of radio-labelled androstenedione to testosterone and oestradiol by the placenta in situ (Licht et al. 1998). These data confirmed that the spotted hyaena placenta expressed both robust 17 $\beta$-hydroxysteroid dehydrogenase activity, enabling testosterone synthesis from androstenedione, and aromatase activity, as previously reported (Yalcinkaya et al. 1993). In the earlier studies on hyaena placentas collected at term, Yalcinkaya and colleagues found aromatase activity to be extremely low compared with activity in human term placentas, and proposed the provocative hypothesis that this might explain high androgen concentrations and 'virilisation' in female foetuses (Yalcinkaya et al. 1993). This idea seemed consistent with the fact that human placental aromatase deficiency was known to be associated with androgenisation of daughters at birth (Shozu et al. 1991, Conte et al. 1994). However, aromatase activity measured in spotted hyaena placentas from early gestation (days 48 and 58) were much higher than those from later in gestation (day 78) (Licht et al. 1998). This temporal pattern was confirmed in a subsequent study (Conley et al. 2007) in which it was shown that hyaena placental aromatase activity was highest at 45 days of gestation, around the time that foetal testicular differentiation and androgen synthesis is occurring. In fact, aromatase activity in hyaena placentas at this stage was nearly one-third of that seen in human placentas at an equivalent point in foetal development. Moreover, there was no obvious difference in aromatase enzyme activity between male and female placentas, though there were too few samples for a truly valid comparison by sex. In any event, the proposed species differential (relative to human placental aromatase activity) was not sufficient to explain 'virilisation' of female foetuses at the most crucial period for hyaena sexual differentiation (Conley et al. 2007). Collectively these data suggested that mechanisms other than placenta steroid synthesis or metabolism were more likely to be relevant in the development of the external genitalia of the female spotted hyaena.

\section{Female genital development: the relative independence from androgen action}

The most direct test of the hypothesis that the external genitalia of the spotted hyaena results from exposure to androgens in utero was tested in a series of experiments designed to minimise androgen synthesis while simultaneously antagonising the effects of androgens at the androgen receptor during foetal development (Drea et al. 1998). The so-called anti-androgen (AA) therapy was achieved by administering a cocktail of flutamide (an androgen receptor antagonist) and finasteride (a $5 \alpha$-reductase inhibitor to minimise $5 \alpha$-dihydrotestosterone synthesis) to females during gestation. It is notable that the androgen receptor of the spotted hyaena does not exhibit constitutive activity in the absence of ligand and ligand activation characteristics are as would be expected from studies in other mammals (Catalano et al. 2002). There was no evidence of constitutive or ligandindependent activity.

This AA treatment of pregnant dams did affect clitoral development of foetal and neonatal offspring from these pregnancies, specifically by minimising the unique sex differences normally observed in this species. In control females from untreated pregnancies, the clitoris is slightly shorter and thicker, the glans is less angular, and the opening of the meatus is much wider, than the male penis. Compared to control female hyaenas, those prenatally exposed to AA had an even shorter clitoris, with an even wider glans and a wider more elastic meatus (Drea et al. 1998). Likewise, AA-exposed male foetuses had penes that exhibited '...the essential morphological characteristics of the female hyaena clitoris (i.e. a shorter, thicker organ, with a large urogenital meatus and a glans with a rounded contour)'. In other words, exposure of foetuses to AA in utero impeded 'masculinisation' in both sexes, effectively 'feminising' the male phallus and exaggerating feminine characteristics of the female phallus (Drea et al. 1998). Anti-androgen treatment during female foetal development did not, however, result in the formation of a typical mammalian vagina and vulva, nor did it affect the formation of the pseudoscrotal pouches in females. Of interest from a comparative perspective, scrotal development in macropod marsupials is X-linked and not an androgen-driven event (Renfree et al. 2002).

There were additional effects on the organisation of the spotted hyaena phallus seen in response to AA exposure of male foetuses and to androgen exposure of female foetuses that were apparent on histological examination (recently reviewed (Cunha et al. 2014)). For instance, the 
retractor penis muscles are located ventral to the urethra, whereas the female phallus has retractor clitoris muscles that are located dorsal to the urogenital canal (Cunha et al. 2005). This appears to be an androgen-sensitive feature and androgen receptor expression in the retractor penis and retractor clitoris muscles was found to be comparable (Cunha et al. 2014). Anti-androgen treatment of pregnant spotted hyaenas effectively relocated the retractor penis muscles of male cubs, shifting them to a dorsal position relative to a more voluminous urethra, mimicking the anatomy of the clitoris (Cunha et al. 2005). The development of the prostate and the tunica albuginea enclosing the urethra also appear to be androgendependent in males (Cunha et al. 2005). Consistent with the response to AA treatment, exposure of a female foetus to a synthetic androgen (mibolerone) resulted in retractor clitoris muscles situated ventral to a 'more compact' urogenital canal (Cunha et al. 2014). In aggregate, these observations indicate that the general architecture of the external genitalia of female and male spotted hyaenas develops in a largely androgen-independent fashion, but that androgens influence the subsequent size, shape of the glans and differentiation of the male penis (Glickman et al. 2006, Cunha et al. 2014) including volume of the urogenital canal. But once again, there is no evidence that the lack of a vulva in female spotted hyaenas derives in any way from exposure to androgens during foetal development as was initially postulated.

\section{Re-evaluation of the endocrinology of the pregnant female}

The repository of samples and tissue specimens from the Berkeley Hyena Project continues to generate novel findings, such as those of the possible evolution of the hemochorial placenta in this carnivoran (Funk et al. 2019), providing further opportunities to examine the unusual biology of this species. We have recently re-examined the endocrinology of pregnancy in spotted hyaenas using liquid chromatography tandem mass spectrometry (LC-MS/MS). The method was developed with an emphasis on progesterone and $5 \alpha$-reduced pregnane metabolites (Legacki et al. 2016), such as $5 \alpha$-dihydroprogesterone (DHP). But, it also includes testosterone and oestrone, and was modified to include cortisol and some unique, but potent, 11-oxygenated androgens (Rege et al. 2019), such as $11 \beta \mathrm{OH}$-androstenedione. Serum samples from untreated, pregnant females and from AA-treated pregnancies were re-examined throughout gestation.
Steroid determinations using LC-MS/MS largely confirmed but also significantly extended what had been found previously in maternal blood in pregnant spotted hyaenas (Licht et al. 1992, Drea et al. 1998, Place et al. 2011). There was an increase in progesterone as pregnancy proceeded $(P<0.01)$ to concentrations exceeding $300 \mathrm{ng} / \mathrm{mL}$ in one case, averaging over $100 \mathrm{ng} / \mathrm{mL}$ overall (Fig. 4A). Testosterone concentrations also increased as pregnancy advanced (Fig. 4C), and androstenedione concentrations declined with time $(P<0.05$; data not shown), but $5 \alpha$-dihydrotestosterone was not detected in any samples. The principal oestrogen detected was oestrone (Fig. 4D), the concentrations of which increased $(P<0.01)$ in concert with testosterone $(r=+0.83, P<0.01)$ in the last 2 months of gestation. Cortisol (Fig. 4E) and corticosterone (data not shown) increased in the final month of gestation $(P<0.01)$, as did the $5 \alpha$-reduced pregnanes,
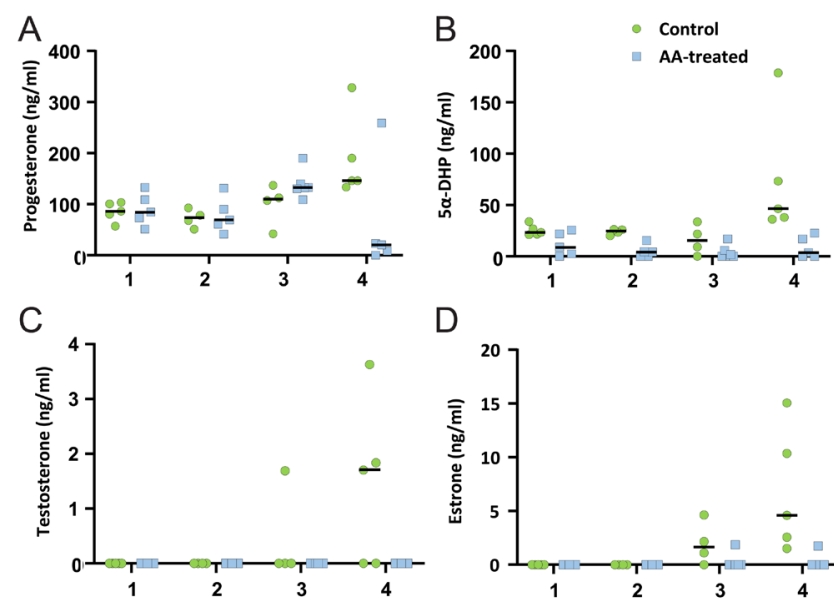

D
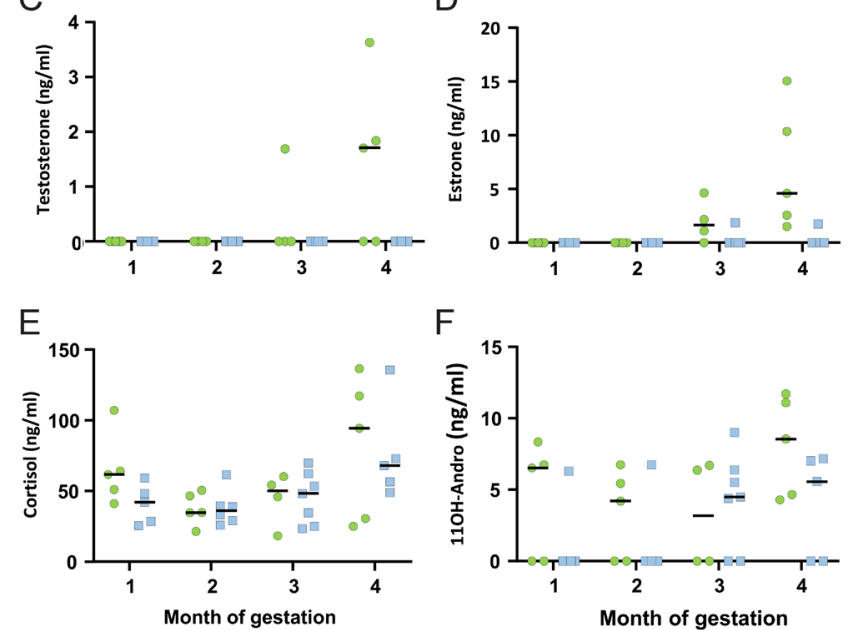

\section{Figure 4}

Steroid concentrations $(\mathrm{ng} / \mathrm{mL})$ in serum from pregnant spotted hyaenas sampled longitudinally throughout pregnancy and analysed by liquid chromatography tandem mass spectrometry in control females ( $n=4-5$, circles) and females receiving anti-androgen (AA) therapy ( $n=5-6$, squares) consisting of flutamide (androgen receptor antagonist) and finasteride ( $5 \alpha$-reductase enzyme inhibitor). Samples were assigned to months 1-4, though the duration of gestation in spotted hyaenas in the colony is slightly less than 4 months (111 days, control; 114 days, anti-androgen-treated (AA)). A, progesterone; $B, 5 \alpha$-dihydroprogesterone (5 $\alpha$-DHP); C, testosterone; D, oestrone; $\mathrm{E}$, cortisol; $\mathrm{F}$,

$11 \mathrm{OH}$-androstenedione (110H-Andro). 
DHP (Fig. 4B, $P<0.01$ ) and allopregnanolone (data not shown), the concentrations of which often exceeded $50 \mathrm{ng} / \mathrm{mL}$. Adrenal androgens, $11 \beta \mathrm{OH}$-androstenedione (Fig. 4F) and 11keto-testosterone (data not shown), were detected and at substantially higher concentrations than are found in most other mammals (Rege et al. 2019).

Consistent with the expected inhibition of $5 \alpha$-reductase enzyme activity by finasteride in the treatment cocktail, DHP was decreased by AA treatment $(P<0.01$, Fig. 4B). More surprisingly, AA treatment markedly depressed testosterone $(P<0.05$, Fig. 4C) and oestrone $(P<0.01$, Fig. 4D) concentrations in late gestation. In addition, a re-examination of the duration of gestation in control and AA-treated females, when mating had actually been observed, demonstrated that AA treatment significantly delayed parturition by 3 days on average $(111.0 \pm 0.4$ vs $114.0 \pm 1.1$, control vs treated, respectively, $P<0.01)$. In fact, it is conceivable that gestation might have been even more extended if AA treatment had not been discontinued near term to avoid potentially adverse sequelae of prolonged gestation. It is curious that oestrone concentrations increase during pregnancy when placental aromatase activity is decreasing (Licht et al. 1998, Conley et al. 2007) to extremely low levels at parturition (Yalcinkaya et al. 1993). The apparent effects of AA treatment on testosterone and oestrone concentrations in late gestation are equally difficult to explain but insight might be provided by studies conducted on sex hormone binding globulin (SHBG) in the Hyaenidae and in samples from pregnant spotted hyaenas.

\section{An unusual SHBG in spotted hyaenas: impact on androgen and oestrogen metabolism and action}

Sex hormone-binding globulins are secreted by the liver and can be found circulating in most sexually mature mammals (Hammond 2016), including spotted hyaenas (van Jaarsveld et al. 1992), influencing the access of sex steroids to target tissues (Siiteri et al. 1982, Westphal 1986). Dependent on their concentrations and affinity for specific steroids, SHBGs can slow sex hormone clearance and decrease free concentrations, thereby affecting steroid access to target tissues. Recent studies on SHBG in all four extant hyaenid species have highlighted key differences in the properties of SHBG in spotted hyaenas compared with their relatives, brown hyaenas, striped hyaenas and aardwolves (Proteles cristatus) (Hammond et al. 2012). Although SHBG sequences are not highly conserved amongst mammals, even within the same taxonomic order (Lee et al. 1997), SHBG shares >98\% identity amongst the four extant hyaenid species. Nevertheless, the SHBG precursor signal sequence that regulates secretion in spotted hyaenas is quite distinct. It lacks three, conserved leucine residues that limit its production, and likely explains the five- to ten-fold lower circulating SHBG concentrations seen in female spotted hyaenas when compared to those seen in the other three hyaenid species (Hammond et al. 2012). It is also notable that the SHBGs of all four hyaenids have a strikingly high affinity for dehydroepiandrosterone and oestrone, a characteristic not shared by other mammals. Furthermore, the apparent affinity of oestrone for the spotted hyaena SHBG is fivefold higher than that for the striped hyaena and the aardwolf (Hammond et al. 2012). This unusual steroidbinding specificity of hyaenid SHBGs cannot explain the reproductive and behavioural phenotypes found only in the spotted hyaena. However, the much lower SHBG concentrations seen in female spotted hyaenas means that oestrone and dehydroepiandrosterone can more effectively displace biologically active sex steroids from their SHBG steroid-binding sites, potentially increasing their free concentrations. The spotted hyaena Shbg gene also seems to be very sensitive to oestrogens because treatment of non-pregnant females with oestradiol valerate increased their plasma SHBG concentrations over a 2 -week period by $>20$-fold from $35 \pm 6$ to $715 \pm 31$ nM. Of particular interest, the concentrations of SHBG in spotted hyaenas were 50-fold higher in late-gestation compared with those in non-pregnant females, increasing from $732 \pm 325$ to $2418 \pm 80 \mathrm{nM}$ between 65 and 95 days of gestation, coincident with increases in both oestrone and testosterone. This extraordinarily robust, pregnancyrelated increase in plasma SHBG is not seen to a comparable degree in other species, and exceeds that seen in human pregnancy (Pearlman et al. 1967, Uriel et al. 1981) by almost an order of magnitude. We have also observed that treatment of pregnant females with the aromatase inhibitor letrozole (to inhibit oestrogen secretion at different stages of gestation) suppressed maternal SHBG concentrations (Supplementary figure 1). It is conceivable that SHBG secretion is also responsive to AA-treatment. In one pregnant female, SHBG concentrations increased $>50$-fold in late gestation but, in a subsequent pregnancy in the same female under AA treatment, no increase was observed (G L Hammond, S E Glickman \& N J Place, unpublished observations). Thus, the lower oestrone and testosterone concentrations seen late in gestation in AA-treated females may be related to low SHBG 
concentrations and higher rates of oestrone clearance. It seems likely that the AA effect on plasma SHBG levels in late gestation also accounts for the surprisingly lower testosterone concentrations mentioned above.

\section{Post-natal development and androgen influences}

Female spotted hyaenas are also interesting as social carnivoransbecause of their unusualbehavioural repertoire, social dominance and size advantage. Aggression emerges unusually early, immediately after birth, in both sexes (Frank et al. 1991), and declines within the first week of life, as social play emerges and rank relations are rapidly established between siblings (Drea et al. 1996). Thereafter, maternal rank and gestational androgen concentrations positively correlate with aggression among juvenile offspring and their peers (Dloniak et al. 2006b). Clans are organised by a well-defined, matriarchal hierarchy, in which females routinely dominate adult, immigrant males (Frank 1986, Smale et al. 1993) and offspring of both sexes acquire a rank, initially just below that of their mother. Because daughters remain in their natal clan, early maternal rank determines their life-time trajectory, whereas sons generally disperse, lose their matrilineal status, and cue for their rank as adults after joining other clans (Smale et al. 1993, East \& Hofer 2001) Still, even after dispersal, sons somehow gain fitness benefits from their mother's high rank (Honer et al. 2010).

In searching for endocrine correlates of social behaviour, it was found that androstenedione concentrations throughout juvenile development are higher in females than males, and relatively constant (Drea et al. 1998), although field studies have not always been in agreement (Goymann et al. 2001). A failure to detect differences under such circumstances might not be surprising given the difficulties posed by field conditions and the more constrained, albeit controlled, environment afforded by a captive colony. In contrast to androstenedione, oestrogen concentrations increase in females after a year of age and they achieve their first pregnancies around 2 years of age in captivity (Glickman et al. 1992b), as in the wild (Frank 1986). Testosterone concentrations increase progressively in males over the same time frame (Glickman et al. 1992b). Importantly, aggressively mediated dominance of females over males is reversed by ovariectomy at an early age (Baker 1990). Specifically, interactions were observed (18:00-22:00 h) between males and females (24-43 months in age) in two separate cohorts (seven females/three males and five females/five males). In addition, two females in the second cohort were ovariectomised at 4-6 months of age. Dyadic aggression (bites, chasing/lunging attacks, displacement of one by another, threatening postures) and submission (avoidance, appeasement postures, crawling) was recorded. Of the mixed-sex interactions observed and averaged across both cohorts, females were 7.5 times more often the aggressors than were males $(P<$ $0.05)$, and males displayed submission three times more often than females $(P<0.06)$. In contrast, ovariectomised females were less often aggressors than intact females in mixed-sex interactions $(P<0.05)$. Ovariectomised females also tended to experience more aggression from a male $(P<0.1)$ and males were significantly more submissive towards intact than ovariectomised females $(P<0.01)$. There was no observed effect of ovariectomy on female to female interactions (Baker 1990).

Contrary to the predominant mammalian paradigm, females are also larger and heavier than males at equivalent ages (Frank 1986, Swanson et al. 2013). These unusual physical characteristics were thought to diverge as the sexes reached the initiation of pubertal development. However, careful longitudinal studies in captivity have demonstrated that the sex disparity in size becomes evident earlier than this, at around a year of age, by which time (and thereafter) females are about 20\% heavier than their male peers (Glickman et al. 1992b). Field studies are generally consistent with this finding, even if the differential is not as great (Swanson et al. 2013, Drea et al. 2018). The lack of a relationship to the onset of puberty suggests this phenomenon is not related to gonadal steroid secretion and growth factor concentrations have been investigated accordingly. Indeed, the female size advantage corresponds with elevated insulin-like growth factor type 1 (IGF-1) concentrations that are higher in females than males $(P<0.05)$ from 6 to 12 months (females: $833.3 \pm 51.7$; males: $613.3 \pm 86.0 \mathrm{ng} / \mathrm{mL}$ ), after which concentrations decline in both sexes from a peak of $723 \pm 57 \mathrm{ng} / \mathrm{mL}$ when averaged together (E M Spencer, P Licht \& S E Glickman, unpublished observations). It is interesting to note that the post-pubertal increase in testosterone in males does not overcome their reduced body weight relative to females (Glickman et al. 1992b).

Other physical traits of spotted hyaenas and their endocrine correlates also merit mention. Notably, there is considerable development of a single, inguinal pair of nipples during the neonatal period. Intact females have larger nipples than do males, from as early as a year of age, but if females are gonadectomised in the first year 
of life, there is a lack of dimorphic nipple development (Glickman et al. 1992b). Similarly, females have a larger opening of the clitoral preputial meatus than males do in the penile preputial meatus, which is evident by 2 months of age (Drea et al. 1998). The sex difference is diminished by gonadectomy, but there is only a marginal effect of gonadectomy on meatal length in males (Glickman et al. $1992 b$, 1998). It appears likely that oestrogens promote both nipple and clitoral development (Glickman et al. 1998). Curiously, the glans of both sexes are also covered by spines and papillae, specialised male adornments in other mammals that are typically under post-natal androgenic control (Aronson \& Cooper 1967, Drea \& Weil 2008). AA treatment modified the appearance of these structures in males and females, implicating an organisational role for androgens in both sexes (Drea et al. 1998), but juvenile gonadectomy had minimal effects (Glickman et al. 1998).

Sexual dimorphisms in the brain have also been observed and documented in spotted hyaenas (Fenstemaker et al. 1999), as they have in spinal motoneurons (Forger et al. 1996). A sexually dimorphic nucleus exists in the medial pre-optic area and anterior hypothalamus of the spotted hyaena that is twice as large in males as in females. This is a relatively modest difference compared to many mammals, and other brain regions were less clearly dimorphic in spotted hyaenas than they are in most mammals (Rosen et al. 2006). Still, the dimorphisms that do exist may have functional relevance. Notably, gonadotropin secretion does exhibit clear, sexually divergent characteristics. Baseline concentrations of luteinising hormone (LH) were higher in female than male hyaenas and maximum concentrations of LH secreted in response to a GnRH challenge were higher in females than males (Place et al. 2002). Anti-androgen treatment during pregnancy had no observable effect on baseline concentrations of LH in offspring of either sex from those dams. Nevertheless, the LH response to GnRH stimulation in both males and females born from AA-treated pregnancies was increased compared with treatmentnaïve contemporaries, and peak concentrations of $\mathrm{LH}$ were maintained 3-4 times longer in females from treated compared with untreated pregnancies. GnRH stimulation elicited significant increases in androstenedione and testosterone in both male and female hyaenas, whether born of naïve (control) or AA-treated dams (Place et al. 2002). While mechanisms remain to be defined, it is clear that reducing androgen exposure of hyaenas in utero influences both the differentiation of the genitalia and the development of the hypothalamic-pituitary axis long after birth.
It is equally as significant that the influence of $\mathrm{AA}$ exposure in utero on the genitalia of neonatal female and male spotted hyaenas persisted post-pubertally, until 30 months of age (adulthood) when profound consequences on reproductive success became apparent (Drea et al.2002). Whereas the enduring feminising effects on the penis ultimately impeded intromission, preventing successful copulation, those on the clitoris facilitated live births in first-time mothers. As adults, those females exposed to AA treatment during development had a clitoral length that was proportionally reduced, the circumference of their clitoral glans was further increased and the clitoral meatus was even larger and more elastic than is typical for females from untreated pregnancies (Drea et al. 2002). Pregnancies were established in these experimental females, as in treatment-naïve contemporaries. Although androstenedione concentrations in the first few months of life were lower in female cubs from AA-treated vs untreated dams (Drea et al. 1998), no differences in steroid concentrations were noted between them as adults. These females, exposed to AA therapy during their development in utero, delivered their first cubs without a single stillbirth, whereas $60 \%$ of first cubs were stillborn when delivered by contemporary controls (Drea et al. 2002). Elasticity and dispensability of the clitoral meatus likely facilitated delivery, which is also likely promoted by placental relaxin secretion that increases in late gestation (Steinetz et al. 1997) as does oestrone. Collectively, the implication of these experiments is that natural exposure to androgen during normal foetal development influences both males and females throughout life, incurring a significant, initial reproductive cost in the case of females (Drea et al. 1998, 2002).

The aggressive and dominance behaviour of females from AA-treated dams was also affected as adults. As infants, aggressive interactions between siblings appeared less intense or less prolonged, such that the otherwise immutable dominance relationship between a set of twin sisters flipped repeatedly over the years (C M Drea, L K Greene, M L Weldele, and S E Glickman, unpublished observations). Again, although androstenedione concentrations in the first few months of life were lower in female cubs from AA-treated vs untreated dams (Drea et al. 1998), no differences in steroid concentrations were noted between them as adults, suggesting organisational vs activational effects. As adults presented with competitive feeding tests in mixed-sex dyads, an 'experimental' female exposed prenatally to AA tolerated a male eating at one of two feeding stations (each with an attached bone), but the contemporary control females aggressively 
fended their male companion away from both stations (M L Weldele \& S E Glickman, unpublished observations), as previously documented (Jenks et al. 1995). Both control and experimental females always won against males when there was a single bone available per pair. There appears to be strong selective pressure for female aggression: within the social hierarchy of the spotted hyaena, in which dominance acquisition is aggressively mediated (Frank 1986), low-ranking females incur a fitness cost relative to high-ranking females (Frank et al. 1995).

\section{Summary and conclusions}

The reproductive biology of the spotted hyaena, as reviewed above, illustrates how narrow our understanding of the biology of sex really is and how adaptable it can be while remaining evolutionarily successful. The spotted hyaena does not redefine sex in a generalisable sense, but emphasises that definitions are only relevant when constructed species by species. The spotted hyaena also illustrates how male-centric and inadequate our generalised definition of genitalia are. Lacking a perineal vulvar opening has imposed functions on the clitoris that defines the anatomical extremes this organ can attain in order to preserve fertility. The elaborate development of the spotted hyaena clitoris, so often defined as 'masculinised', is largely independent of, and notably protected from, androgenisation during its development when androgenisation is otherwise so important in other processes including neural organisation. Perhaps it is not too surprising then that the androgen receptor itself appears to be unexceptional in the spotted hyaena, functioning on a biochemical level much as it does in other species. The endocrinology of the pregnant spotted hyaena is unusual in terms of the increasing and high peak concentrations of progesterone, testosterone and oestrone. The properties of SHBG in spotted hyaenas is also notable in exhibiting characteristics not seen in other species, and appears to have a major influence on steroid concentrations during late gestation. A marked increase in circulating SHBG concentrations during pregnancy appears to promote high concentrations of both testosterone and oestrone, presumptively by decreasing clearance. At the same time, SHBG concentrations during pregnancy are clearly sensitive to oestrogens and perhaps even to androgens. The ultimate effects of this steroid environment influence behaviours post-natally which has an equally important impact on reproductive success. In a broader sense, exposure of pregnant dams and their developing foetuses to AA treatment further illustrates, in a unique way, just how delicate an anatomical and physiological balance is struck in this species. Relieving female foetuses of the anatomical burden of androgens increased their reproductive success during birth (especially their first) but precluded males exposed as foetuses from successfully mating females after reaching sexual maturity. The spotted hyaena demonstrates how the more common anatomic and physiologic paradigms are not essential for evolutionary fitness and survival. Reproductive strategies do not have to make sense to us if they create viable, reproductively successful offspring. In fact, variations in reproductive biology provide confidence that adaptation and continued reproductive success are possible in ever-changing environments, and only those species that can adapt rapidly enough will be guaranteed a chance of survival.

The studies described above expose weaknesses in our narrow understanding of the mechanisms of sexual differentiation, particularly as regards establishment of the female form (Drea et al. 1998), and illustrate how variations in reproductive biology can be adaptable and evolutionarily successful, in this case exemplifying sexual selection operating in females. Despite displaying a suite of 'masculinised' traits, the female spotted hyaena does not defy any standard definition of sex (sex chromosome constitution, gametes, gonads, genitalia or phenotype). She has two X chromosomes, a functional ovary with a Müllerian ductal system, a uterus and a vaginal cavity even if not engaged with a penis during copulation, and she engages in female-typical mating behaviour, successfully develops a placenta, bears young, nurses them for an exceptionally long period and shows appropriate maternal behaviour. Moreover, she is certainly not alone in possessing a hypertrophied clitoris (e.g. proboscideans, elephant (Glickman et al. 2005); primates including platyrrhines (Campbell 2017, Carosi et al. 2020), strepsirrhines and others (Hill 1953, Dixson 1998, Drea \& Weil 2008); viverrids (Hawkins et al. 2002); talpids (Sinclair et al. 2017)), suggesting that successful birth via this structure is what, ironically, derails notions about her femininity. These incongruities illustrate the inadequacy of a male-centric definition of reproductive biology.

The environment of the captive colony of spotted hyaenas was necessarily artificial, physically and socially. However, it provided a level of control over factors potentially influencing and possibly obscuring underlying biological differences that, therefore, may be difficult to observe otherwise. This may explain apparent discrepancies in data from colony and field studies. 
Body size is perhaps a case in point. While many studies report that females are heavier than males, the differentials averaging perhaps 10\% in the field (Drea et al. 2018) are much less than the $20 \%$ observed in the colony (Glickman et al. 1992b). Whether or not this reflects the controlled environment or a plentiful diet, it still suggests an underlying biological difference between the sexes. Moreover, no field data exist indicating that spotted hyaena males are heavier on average than females, which is in itself significant enough. Although the current review has focused primarily on reproductive endocrinology, the captive colony enabled studies on a broad range of topics in social behaviour, behavioural development and social psychology, including dominance and aggression (Zabel et al. 1992, Jenks et al. 1995, Wahaj et al. 2007), behavioural flexibility (Holekamp et al. 2013), prosociality and socialisation (Pedersen et al. 1990, Rifkin \& Glickman 2004), vocal and olfactory communication (Woodmansee et al. 1991, Drea et al. 1996, Mathevon et al. 2010), feeding (Binder \& Van Valkenburgh 2000), cognition (Yoerg 1991, Drea \& Carter 2009) and personality (Gosling 1998), as well as other biological phenomena such as immune function (Flies et al. 2012). It is hoped these observations will find their way into future reviews, updating and expanding on those already published (Glickman 1995, Glickman et al. 1997, 2006, Drea \& Frank 2003, Cunha et al. 2014). But it is also hoped that the lessons from these investigations convincingly underscore the value of comparative biology and the pressing need to study exotic species before they become extinct.

\section{Supplementary materials}

This is linked to the online version of the paper at https://doi.org/10.1530/ JOE-20-0252.

\section{Declaration of interest}

The authors declare that there is no conflict of interest that could be perceived as prejudicing the impartiality of this review.

\section{Funding}

This work was funded in large measure by the National Institutes of Health (HD07684) and National Science Foundation (IOS-0920793).

\section{Author contribution statement}

A Conley contributed to study design, collection and analysis of data, compiled figures, drafted the manuscript, collated editorial comments from co-authors and revised the manuscript accordingly, addressed issues raised by reviewers and coordinated revisions. $\mathrm{N} J$ Place contributed to study design, collected and compiled samples, revised the manuscript. E L Legacki organised and analysed samples and data, revised the manuscript. G L Hammond contributed to study design, collection and analysis of samples, writing and revision of the manuscript. G R Cunha procured funding, contributed to study design, writing and revision of the manuscript. C M Drea contributed to writing and revising the manuscript and helped address issues raised by reviewers. M L Weldele contributed to collection and compilation of samples. S E Glickman conceived the manuscript, procured funding, designed studies, collected and compiled samples, and was a friend and an inspiration to all of us.

\section{Acknowledgements}

The authors would like to dedicate this review to Prof Stephen E Glickman, who passed away as this manuscript was being submitted and to others who contributed but are no longer with us, Drs Mel Grumbach and Penti Siiteri. If the spotted hyaena is an 'experiment of nature', then the Berkeley Hyena Project has been an 'experiment of scientific culture and collaboration'. During a period of almost three decades, Prof Glickman brought together and guided a diverse and distinguished cadre of scientists whose single common interest and curiosity was the unique biology of this species. The Berkeley Field Station that housed the hyaena colony was established in part with support from Prof Frank Beach after he moved from Yale University to the Berkeley campus. As one of our reviewers noted, Prof Beach was an avid proponent of truly comparative biology. This was exemplified in his classic Presidential address entitled 'The Snark was a Boojum' which was delivered before the Division of Experimental Psychology of the American Psychological Association on September 7, 1949 (Beach 1950). In a memorandum, the Berkeley Field Station has been renamed in honour of Prof Glickman.

\section{References}

Aronson LR \& Cooper ML 1967 Penile spines of the domestic cat: their endocrine-behavior relations. Anatomical Record 157 71-78. (https:// doi.org/10.1002/ar.1091570111)

Baker MG 1990 Effects of ovariectomy on dyadic aggression and submission in a colony of peripubertal spotted hyaenas (Crocuta crocuta). Master of Science Thesis, University of California, Berkeley.

Balke JM, Boever WJ, Ellersieck MR, Seal US \& Smith DA 1988 Anatomy of the reproductive tract of the female African elephant (Loxodonta africana) with reference to development of techniques for artificial breeding. Journal of Reproduction and Fertility 84 485-492. (https://doi. org/10.1530/jrf.0.0840485)

Beach FA 1950 The snark was a boojum. American Psychologist 5 115-124. (https://doi.org/10.1037/h0056510)

Bewell A 2014 Hyena trouble. Studies in Romanticism 53 969-397. (https:// doi.org/10.1353/srm.2014.0004)

Binder WJ \& Van Valkenburgh B 2000 Development of bite strength and feeding behaviour in juvenile spotted hyenas (Crocuta crocuta). Journal of Zoology 252 273-283. (https://doi. $\operatorname{org} / 10.1111 /$ j.1469-7998.2000.tb00622.x)

Blaschko SD, Cunha GR \& Baskin LS 2012 Molecular mechanisms of external genitalia development. Differentiation: Research in Biological Diversity 84 261-268. (https://doi.org/10.1016/j.diff.2012.06.003)

Boydston EE, Morelli TL \& Holekamp KE 2001 Sex differences in territorial behavior exhibited by the spotted hyena (Hyaenidae, Crocuta crocuta). Ethology 107 369-385. (https://doi.org/10.1046/ j.1439-0310.2001.00672.x)

Browne P, Place NJ, Vidal JD, Moore IT, Cunha GR, Glickman SE \& Conley AJ 2006 Endocrine differentiation of fetal ovaries and 
testes of the spotted hyena (Crocuta crocuta): timing of androgenindependent versus androgen-driven genital development. Reproduction 132 649-659. (https://doi.org/10.1530/rep.1.01120)

Campbell CJ 2017 Hypertrophied clitoris. In The International Encyclopedia of Primatology. Ed A Fuentes. New York, NY, USA: JohnWiley \& Sons, Inc.

Carosi M, Spani F, Ulland AE, Scalici M \& Suomi SJ 2020 Clitoral length in immature and mature captive tufted capuchin (Sapajus spp.) females: a cross-sectional study. American Journal of Primatology e23135. (https://doi.org/10.1002/ajp.23135)

Catalano S, Avila DM, Marsico S, Wilson JD, Glickman SE \& McPhaul MJ 2002 Virilization of the female spotted hyena cannot be explained by alterations in the amino acid sequence of the androgen receptor (AR). Molecular and Cellular Endocrinology 194 85-94. (https://doi. org/10.1016/s0303-7207(02)00179-x)

Conley AJ, Corbin CJ, Browne P, Mapes SM, Place NJ, Hughes AL \& Glickman SE 2007 Placental expression and molecular characterization of aromatase cytochrome P450 in the spotted hyena (Crocuta crocuta). Placenta 28 668-675. (https://doi.org/10.1016/j.placenta.2006.11.004)

Conte FA, Grumbach MM, Ito Y, Fisher CR \& Simpson ER 1994 A syndrome of female pseudohermaphrodism, hypergonadotropic hypogonadism, and multicystic ovaries associated with missense mutations in the gene encoding aromatase P450arom. Journal of Clinical Endocrinology and Metabolism 78 1287-1292. (https://doi. org/10.1210/jcem.78.6.8200927)

Cunha GR, Wang Y, Place NJ, Liu W, Baskin L \& Glickman SE 2003 Urogenital system of the spotted hyena (Crocuta crocuta Erxleben): a functional histological study. Journal of Morphology 256 205-218. (https://doi.org/10.1002/jmor.10085)

Cunha GR, Place NJ, Baskin L, Conley A, Weldele M, Cunha TJ, Wang YZ, Cao M \& Glickman SE 2005 The ontogeny of the urogenital system of the spotted hyena (Crocuta crocuta Erxleben). Biology of Reproduction 73 554-564. (https://doi.org/10.1095/ biolreprod.105.041129)

Cunha GR, Risbridger G, Wang H, Place NJ, Grumbach M, Cunha TJ, Weldele M, Conley AJ, Barcellos D, Agarwal S, et al. 2014 Development of the external genitalia: perspectives from the spotted hyena (Crocuta crocuta). Differentiation: Research in Biological Diversity 87 4-22. (https://doi.org/10.1016/j.diff.2013.12.003)

Cunha GR, Liu G, Sinclair A, Cao M, Glickman S, Cooke PS \& Baskin L 2020 Androgen-independent events in penile development in humans and animals. Differentiation: Research in Biological Diversity 111 98-114. (https://doi.org/10.1016/j.diff.2019.07.005)

Dixson AF 1998 Sexual selection and genital evolution. In Primate Sexuality: Comparative Studies of the Prosimians, Monkeys, Apes, and Human Beings. Oxford, UK: Oxford University Press.

Dloniak SM, French JA, Place NJ, Weldele ML, Glickman SE \& Holekamp KE 2004 Non-invasive monitoring of fecal androgens in spotted hyenas (Crocuta crocuta). General and Comparative Endocrinology 135 51-61. (https://doi.org/10.1016/j.ygcen.2003.08.011)

Dloniak SM, French JA \& Holekamp KE 2006a Faecal androgen concentrations in adult male spotted hyaenas, Crocuta crocuta, reflect interactions with socially dominant females. Animal Behaviour $\mathbf{7 1}$ 27-37. (https://doi.org/10.1016/j.anbehav.2005.03.016)

Dloniak SM, French JA \& Holekamp KE 2006b Rank-related maternal effects of androgens on behaviour in wild spotted hyaenas. Nature 440 1190-1193. (https://doi.org/10.1038/nature04540)

Drea CM \& Carter AN 2009 Cooperative problem solving in a social carnivore. Animal Behaviour 78 967-977. (https://doi.org/10.1016/j. anbehav.2009.06.030)

Drea CM \& Frank LG 2003 The social complexity of spotted hyenas. In Animal Social Complexity: Intelligence, Culture, and Individualized Societies. Eds FBM De Waal \& PL Tyack. Cambridge, MA, USA: Harvard University Press.

Drea CM \& Weil A 2008 External genital morphology of the ring-tailed lemur (Lemur catta): females are naturally 'masculinized'. Journal of Morphology 269 451-463. (https://doi.org/10.1002/jmor.10594)
Drea CM, Hawk JE \& Glickman SE 1996 Aggression decreases as play emerges in infant spotted hyaenas: preparation for joining the clan. Animal Behaviour 51 1323-1336. (https://doi.org/10.1006/ anbe.1996.0136)

Drea CM, Weldele ML, Forger NG, Coscia EM, Frank LG, Licht P \& Glickman SE 1998 Androgens and masculinization of genitalia in the spotted hyaena (Crocuta crocuta). 2. Effects of prenatal antiandrogens. Journal of Reproduction and Fertility 113 117-127. (https:// doi.org/10.1530/jrf.0.1130117)

Drea CM, Place NJ, Weldele ML, Coscia EM, Licht P \& Glickman SE 2002 Exposure to naturally circulating androgens during foetal life incurs direct reproductive costs in female spotted hyenas, but is prerequisite for male mating. Proceedings. Biological Sciences 269 1981-1987. (https://doi.org/10.1098/rspb.2002.2109)

Drea CM, Coscia EM \& Glickman SE 2018 Hyenas. In Encyclopedia of Reproduction, 2nd ed. Eds E Knobil, J Neill \& P Licht. San Diego, CA, USA: Academic Press.

East ML \& Hofer H 2001 Male spotted hyenas (Crocuta crocuta) queue for status in social groups dominated by females. Behavioral Ecology $\mathbf{1 2}$ 558-568. (https://doi.org/10.1093/beheco/12.5.558)

East ML, Hofer H \& Wickler W 1993 The erect 'penis' is a flag of submission in a female-dominated society: greetings in Serengeti spotted hyenas. Behavioral Ecology and Sociobiology 33 355-370. (https://doi.org/10.1007/BF00170251)

Enders AC, Blankenship TN, Conley AJ \& Jones CJ 2006 Structure of the midterm placenta of the spotted hyena, Crocuta crocuta, with emphasis on the diverse hemophagous regions. Cells, Tissues, Organs 183 141-155. (https://doi.org/10.1159/000095988)

Enders A, Blankenship T \& Conley A 2007 Comparison of the hemochorial placental labyrinth of the hyena with the endotheliochorial labyrinth of mustelids. Biology of Reproduction $\mathbf{7 7}$ 101-102. (https://doi.org/10.1093/biolreprod/77.s1.101d)

Fenstemaker SB, Zup SL, Frank LG, Glickman SE \& Forger NG 1999 A sex difference in the hypothalamus of the spotted hyena. Nature Neuroscience 2 943-945. (https://doi.org/10.1038/14728)

Flies AS, Grant CK, Mansfield LS, Smith EJ, Weldele ML \& Holekamp KE 2012 Development of a hyena immunology toolbox. Veterinary Immunology and Immunopathology 145 110-119. (https://doi. org/10.1016/j.vetimm.2011.10.016)

Forger NG, Frank LG, Breedlove SM \& Glickman SE 1996 Sexual dimorphism of perineal muscles and motoneurons in spotted hyenas. Journal of Comparative Neurology 375 333-343. (https:// doi.org/10.1002/(SICI)1096-9861(19961111)375:2<333::AIDCNE11>3.0.CO;2-W)

Frank LG 1986 Social organization of the spotted hyaena (Crocuta crocuta). II. Dominance and reproduction. Animal Behaviour 34 1510-1527. (https://doi.org/10.1016/S0003-3472(86)80221-4)

Frank LG, Glickman SE \& Powch I 1990 Sexual dimorphism in the spotted hyena (Crocuta crocuta). Journal of Zoology 221 308-313. (https://doi.org/10.1111/j.1469-7998.1990.tb04001.x)

Frank LG, Glickman SE \& Licht P 1991 Fatal sibling aggression, precocial development, and androgens in neonatal spotted hyenas. Science $\mathbf{2 5 2}$ 702-704. (https://doi.org/10.1126/science.2024122)

Frank LG, Holekamp KE \& Smale L 1995 Dominance, demography and reproductive success of female spotted hyenas. In Serengeti II Dynamics, Management, and Conservation of an Ecosystem. Eds ARE Sinclair \& P Arcese. Chicago, IL, USA: University of Chicago Press.

Frazer JFD \& Huggett ASG 1974 Species variations in the foetal growth rates of eutherian mammals. Journal of Zoology 174 481-509. (https:// doi.org/10.1111/j.1469-7998.1974.tb03173.x)

Funk M, Cornelis G, Vernochet C, Heidmann O, Dupressoir A, Conley A, Glickman S \& Heidmann T 2019 Capture of a hyena-specific retroviral envelope gene with placental expression associated in evolution with the unique emergence among carnivorans of hemochorial placentation in Hyaenidae. Journal of Virology 93 e01811-e01818. (https://doi.org/10.1128/JVI.01811-18) https://joe.bioscientifica.com

https://doi.org/10.1530/JOE-20-0252 (c) 2020 Society for Endocrinology Published by Bioscientifica Ltd.
Printed in Great Britain 
George FW \& Wilson JD 1994 Sex determination and differentiation. In The Physiology of Reproduction. Eds E Knobil \& JD Neill. New York, NY, USA: Raven Press.

Glickman SE 1995 The spotted hyena from Aristotle to the Lion King: reputation is everything. Social Research 62 501-537.

Glickman SE, Frank LG, Davidson JM, Smith ER \& Siiteri PK 1987 Androstenedione may organize or activate sex-reversed traits in female spotted hyenas. PNAS 84 3444-3447. (https://doi.org/10.1073/ pnas.84.10.3444)

Glickman SE, Frank LG, Licht P, Yalcinkaya T, Siiteri PK \& Davidson J $1992 a$ Sexual differentiation of the female spotted hyena. One of nature's experiments. Annals of the New York Academy of Sciences 662 135-159. (https://doi.org/10.1111/j.1749-6632.1992.tb22858.x)

Glickman SE, Frank LG, Pavgi S \& Licht P 1992b Hormonal correlates of 'masculinization' in female spotted hyaenas (Crocuta crocuta). 1. Infancy to sexual maturity. Journal of Reproduction and Fertility 95 451-462. (https://doi.org/10.1530/jrf.0.0950451)

Glickman SE, Zabel CJ, Yoerg SI, Weldele ML, Drea CM \& Frank LG 1997 Social facilitation, affiliation, and dominance in the social life of spotted hyenas. Annals of the New York Academy of Sciences $\mathbf{8 0 7}$ 175-184. (https://doi.org/10.1111/j.1749-6632.1997.tb51919.x)

Glickman SE, Coscia EM, Frank LG, Licht P, Weldele ML \& Drea CM 1998 Androgens and masculinization of genitalia in the spotted hyaena (Crocuta crocuta). 3. Effects of juvenile gonadectomy. Journal of Reproduction and Fertility 113 129-135. (https://doi.org/10.1530/ jrf.0.1130129)

Glickman SE, Short RV \& Renfree MB 2005 Sexual differentiation in three unconventional mammals: spotted hyenas, elephants and tammar wallabies. Hormones and Behavior 48 403-417. (https://doi. org/10.1016/j.yhbeh.2005.07.013)

Glickman SE, Cunha GR, Drea CM, Conley AJ \& Place NJ 2006 Mammalian sexual differentiation: lessons from the spotted hyena. Trends in Endocrinology and Metabolism 17 349-356. (https://doi. org/10.1016/j.tem.2006.09.005)

Gosling SD 1998 Personality dimensions in spotted hyenas (Crocuta crocuta). Journal of Comparative Psychology 112 107-118. (https://doi. org/10.1037/0735-7036.112.2.107)

Gould SJ 1983 Hyena myths and realities. In Hen's Teeth and Horses Toes. New York, NY, USA: Norton.

Goy RW, Bercovitch FB \& McBrair MC 1988 Behavioral masculinization is independent of genital masculinization in prenatally androgenized female rhesus macaques. Hormones and Behavior 22 552-571. (https:// doi.org/10.1016/0018-506x(88)90058-x)

Goymann W, East ML \& Hofer H 2001 Androgens and the role of female 'hyperaggressiveness' in spotted hyenas (Crocuta crocuta). Hormones and Behavior 39 83-92. (https://doi.org/10.1006/hbeh.2000.1634)

Griffin JE, McPhaul MJ, Russell DW \& Wilson JD 2001 The androgen resistance syndromes: steroid 5alpha-reductase 2 deficiency, testicular feminization, and related disorders. In The Metabolic and Molecular Basis of Inherited Disease, 8th ed. New York, NY, USA: McGraw-Hill.

Gustafson ML \& Donahoe PK 1994 Male sex determination: current concepts of male sexual differentiation. Annual Review of Medicine $\mathbf{4 5}$ 505-524. (https://doi.org/10.1146/annurev.med.45.1.505)

Hamilton III WJ, Tilson RL \& Frank LG 1986 Sexual monomorphism in spotted hyenas, Croctrta crocuta. Ethology 71 63-73.

Hammond GL 2016 Plasma steroid-binding proteins: primary gatekeepers of steroid hormone action. Journal of Endocrinology 230 R13-R25. (https://doi.org/10.1530/JOE-16-0070)

Hammond GL, Miguel-Queralt S, Yalcinkaya TM, Underhill C, Place NJ, Glickman SE, Drea CM, Wagner AP \& Siiteri PK 2012 Phylogenetic comparisons implicate sex hormone-binding globulin in 'masculinization' of the female spotted hyena (Crocuta crocuta). Endocrinology 153 1435-1443. (https://doi.org/10.1210/en.2011-1837)

Hawkins CE, Dallas JF, Fowler PA, Woodroffe R \& Racey PA 2002 Transient masculinization in the fossa, Cryptoprocta ferox
(Carnivora, Viverridae). Biology of Reproduction 66 610-615. (https:// doi.org/10.1095/biolreprod66.3.610)

Henschel JR \& Skinner JD 1991 Territorial behaviour by a clan of spotted hyaenas Crocuta crocuta. Ethology 88 223-235. (https://doi. org/10.1111/j.1439-0310.1991.tb00277.x)

Herman RA, Jones B, Mann DR \& Wallen K 2000 Timing of prenatal androgen exposure: anatomical and endocrine effects on juvenile male and female rhesus monkeys. Hormones and Behavior 38 52-66. (https://doi.org/10.1006/hbeh.2000.1608)

Hill WCO 1953 Primates (Comparative Anatomy and Taxonomy). Edinburgh, UK: University Press.

Holekamp KE, Swanson EM \& Van Meter PE 2013 Developmental constraints on behavioural flexibility. Philosophical Transactions of the Royal Society of London: Series B, Biological Sciences 36820120350. (https://doi.org/10.1098/rstb.2012.0350)

Honer OP, Wachter B, Hofer H, Wilhelm K, Thierer D, Trillmich F, Burke T \& East ML 2010 The fitness of dispersing spotted hyaena sons is influenced by maternal social status. Nature Communications $\mathbf{1} 60$. (https://doi.org/10.1038/ncomms1059)

Huggett AS \& Widdas WF 1951 The relationship between mammalian foetal weight and conception age. Journal of Physiology 114 306-317. (https://doi.org/10.1113/jphysiol.1951.sp004622)

Jenks SM, Weldele ML, Frank LG \& Glickman SE 1995 Acquisition of matrilineal rank in captive spotted hyaenas: emergence of a natural social system in peer-reared animals and their offspring. Animal Behaviour 50 893-904. (https://doi.org/10.1016/00033472(95)80092-1)

Jost A 1948 Le controle hormonal de la differenciation du sexe. Biological Reviews of the Cambridge Philosophical Society 23 201-236. (https://doi. org/10.1111/j.1469-185x.1948.tb00462.x)

Jost A 1970 Hormonal factors in the sex differentiation of the mammalian foetus. Philosophical Transactions of the Royal Society of London: Series B, Biological Sciences 259 119-130. (https://doi. org/10.1098/rstb.1970.0052)

Jost A 1991 Twists and turns of research - the study of sexualdifferentiation. Medecine Sciences 7 263-275.

Jost A, Vigier B, Prepin J \& Perchellet JP 1973 Studies on sex differentiation in mammals. Recent Progress in Hormone Research 29 1-41. (https://doi.org/10.1016/b978-0-12-571129-6.50004-x)

Lee WM, Wong AS, Tu AW, Cheung CH, Li JC \& Hammond GL 1997 Rabbit sex hormone binding globulin: primary structure, tissue expression, and structure/function analyses by expression in Escherichia coli. Journal of Endocrinology 153 373-384. (https://doi. org/10.1677/joe.0.1530373)

Legacki EL, Scholtz EL, Ball BA, Stanley SD, Berger T \& Conley AJ 2016 The dynamic steroid landscape of equine pregnancy mapped by mass spectrometry. Reproduction 151 421-430. (https://doi.org/10.1530/ REP-15-0547)

Licht P, Frank LG, Pavgi S, Yalcinkaya TM, Siiteri PK \& Glickman SE 1992 Hormonal correlates of 'masculinization' in female spotted hyaenas (Crocuta crocuta). 2. Maternal and fetal steroids. Journal of Reproduction and Fertility 95 463-474. (https://doi.org/10.1530/ jrf.0.0950463)

Licht P, Hayes T, Tsai P, Cunha G, Kim H, Golbus M, Hayward S, Martin MC, Jaffe RB \& Glickman SE 1998 Androgens and masculinization of genitalia in the spotted hyaena (Crocuta crocuta). 1. Urogenital morphology and placental androgen production during fetal life. Journal of Reproduction and Fertility 113 105-116. (https://doi. org/10.1530/jrf.0.1130105)

Lindeque M \& Skinner JD 1982 Fetal androgens and sexual mimicry in spotted hyaenas (Crocuta crocuta). Journal of Reproduction and Fertility 65 405-410. (https://doi.org/10.1530/jrf.0.0650405)

Lindeque M, Skinner JD \& Millar RP 1986 Adrenal and gonadal contribution to circulating androgens in spotted hyaenas (Crocuta crocuta) as revealed by LHRH, hCG and ACTH stimulation. Journal https://joe.bioscientifica.com

https://doi.org/10.1530/JOE-20-0252
(C) 2020 Society for Endocrinology Published by Bioscientifica Ltd. Printed in Great Britain 
of Reproduction and Fertility $\mathbf{7 8}$ 211-217. (https://doi.org/10.1530/ jrf.0.0780211)

Mathevon N, Koralek A, Weldele M, Glickman SE \& Theunissen FE 2010 What the hyena's laugh tells: sex, age, dominance and individual signature in the giggling call of Crocuta crocuta. BMC Ecology 109. (https://doi.org/10.1186/1472-6785-10-9)

Matthews LH 1939 Reproduction in the spotted hyaena, Crocuta crocuta (erxleben). Proceedings of the Royal Society of London Series B 230 1-78.

Matthews R 1987 Leonard Harrison Matthews. 12 June 1901-27 November 1986. Biographical Memoirs of Fellows of the Royal Society 33 412-442.

Moran FM, Ford JJ, Corbin CJ, Mapes SM, Njar VC, Brodie AM \& Conley AJ 2002 Regulation of microsomal P450, redox partner proteins, and steroidogenesis in the developing testes of the neonatal pig. Endocrinology 143 3361-3369. (https://doi.org/10.1210/en.2002220329)

Neaves WB, Griffin JE \& Wilson JD 1980 Sexual dimorphism of the phallus in spotted hyaena (Crocuta crocuta). Journal of Reproduction and Fertility 59 509-513. (https://doi.org/10.1530/jrf.0.0590509)

Pearlman WH, Crepy O \& Murphy M 1967 Testosterone-binding levels in the serum of women during the normal menstrual cycle, pregnancy, and the post-partum period. Journal of Clinical Endocrinology and Metabolism 27 1012-1018. (https://doi.org/10.1210/jcem-27-7-1012)

Pedersen JM, Glickman SE, Frank LG \& Beach FA 1990 Sex differences in the play behavior of immature spotted hyenas, Crocuta crocuta. Hormones and Behavior 24 403-420. (https://doi.org/10.1016/0018$506 x(90) 90018$-s)

Perry JS 1964 The structure and development of the reproductive organs of the African elephant. Philosophical Transactions of the Royal Society of London Series B 248 35-51.

Phoenix CH, Goy RW, Gerall AA \& Young WC 1959 Organizing action of prenatally administered testosterone propionate on the tissues mediating mating behavior in the female guinea pig. Endocrinology 65 369-382. (https://doi.org/10.1210/endo-65-3-369)

Place NJ, Holekamp KE, Sisk CL, Weldele ML, Coscia EM, Drea CM \& Glickman SE 2002 Effects of prenatal treatment with antiandrogens on luteinizing hormone secretion and sex steroid concentrations in adult spotted hyenas, Crocuta crocuta. Biology of Reproduction $\mathbf{6 7}$ 1405-1413. (https://doi.org/10.1095/biolreprod.102.004226)

Place NJ, Coscia EM, Dahl NJ, Drea CM, Holekamp KE, Roser JF, Sisk CL, Weldele ML \& Glickman SE 2011 The anti-androgen combination, flutamide plus finasteride, paradoxically suppressed LH and androgen concentrations in pregnant spotted hyenas, but not in males. General and Comparative Endocrinology 170 455-459. (https://doi. org/10.1016/j.ygcen.2010.10.016)

Racey PA \& Skinner JD 1979 Endocrine aspects of sexual mimicry in Spotted hyaenas Crocuta crocuta. Journal of Zoology 187 315-326. (https://doi.org/10.1111/j.1469-7998.1979.tb03372.x)

Rege J, Garber S, Conley AJ, Elsey RM, Turcu AF, Auchus RJ \& Rainey WE 2019 Circulating 11-oxygenated androgens across species. Journal of Steroid Biochemistry and Molecular Biology 190 242-249. (https://doi. org/10.1016/j.jsbmb.2019.04.005)

Renfree MB, Wilson JD \& Shaw G 2002 The hormonal control of sexual development. Novartis Foundation Symposium 244 136-152; discussion 152. (https://doi.org/10.1002/0470868732.ch12)

Rey RA \& Grinspon RP 2011 Normal male sexual differentiation and aetiology of disorders of sex development. Best Practice and Research: Clinical Endocrinology and Metabolism 25 221-238. (https://doi. org/10.1016/j.beem.2010.08.013)

Rifkin A \& Glickman SE 2004 Separation as a natural cue to danger in the spotted hyena (Crocuta crocuta). Developmental Psychobiology 44 199-207. (https://doi.org/10.1002/dev.20003)

Rosen GJ, De Vries GJ, Villalba C, Weldele ML, Place NJ, Coscia EM, Glickman SE \& Forger NG 2006 Distribution of vasopressin in the forebrain of spotted hyenas. Journal of Comparative Neurology 498 80-92. (https://doi.org/10.1002/cne.21032)

Schultz FM \& Wilson JD 1974 Virilization of the Wolffian duct in the rat fetus by various androgens. Endocrinology 94 979-986. (https://doi. org/10.1210/endo-94-4-979)

Shaw G \& Renfree MB 2014 Wolffian duct development. Sexual Development 8 273-280. (https://doi.org/10.1159/000363432)

Shozu M, Akasofu K, Harada T \& Kubota Y 1991 A new cause of female pseudohermaphrodism: placental aromatase deficiency. Journal of Clinical Endocrinology and Metabolism 72 560-566. (https://doi. org/10.1210/jcem-72-3-560)

Siiteri PK, Murai JT, Hammond GL, Nisker JA, Raymoure WJ \& Kuhn RW 1982 The serum transport of steroid hormones. Recent Progress in Hormone Research 38 457-510. (https://doi.org/10.1016/b978-0-12571138-8.50016-0)

Sinclair AW, Glickman S, Catania K, Shinohara A, Baskin L \& Cunha GR 2017 Comparative morphology of the penis and clitoris in four species of moles (Talpidae). Journal of Experimental Zoology: Part B, Molecular and Developmental Evolution 328 275-294. (https://doi. org/10.1002/jez.b.22732)

Smale LL, Frank LG \& Holekamp KE 1993 Ontogeny of dominance in free-living spotted hyaenas: juvenile rank relations with adult females and immigrant males. Animal Behaviour 46 467-477. (https://doi. org/10.1006/anbe.1993.1215)

Sobel V, Zhu YS \& Imperato-McGinley J 2004 Fetal hormones and sexual differentiation. Obstetrics and Gynecology Clinics of North America 31 837-856, x. (https://doi.org/10.1016/j.ogc.2004.08.005)

Steinetz BG, Randolph C, Weldele M, Frank LG, Licht P \& Glickman SE 1997 Pattern and source of secretion of relaxin in the reproductive cycle of the spotted hyena (Crocuta crocuta). Biology of Reproduction 56 1301-1306. (https://doi.org/10.1095/biolreprod56.5.1301)

Swanson EM, McElhinny TL, Dworkin I, Weldele ML, Glickman SE \& Holekamp KE 2013 Ontogeny of sexual size dimorphism in the spotted hyena (Crocuta crocuta). Journal of Mammalogy 94 1298-1310. (https://doi.org/10.1644/12-MAMM-A-277.1)

Szczygielska M 2017 Hyenas and hormones: transpecies encounters and the traffic in humanimals. Angelaki 22 61-84. (https://doi.org/10.108 0/0969725X.2017.1322820)

Uriel J, Dupiers M, Rimbaut C \& Buffe D 1981 Maternal serum levels of sex steroid-binding protein during pregnancy. British Journal of Obstetrics and Gynaecology 88 1229-1232. (https://doi. org/10.1111/j.1471-0528.1981.tb01202.x)

Van Jaarsveld AS \& Skinner JD 1991 Plasma androgens in spotted hyaenas (Crocuta crocuta): influence of social and reproductive development. Journal of Reproduction and Fertility 93 195-201. (https://doi. org/10.1530/jrf.0.0930195)

Van Jaarsveld AS, Van Aarde RJ, Skinner JD \& Van Wyk V 1992 Sexspecific androgen binding in spotted hyaena (Crocuta crocuta) plasma. Comparative Biochemistry and Physiology Part A: Physiology 103 319-322. (https://doi.org/10.1016/0300-9629(92)90587-g)

Van Meter PE, French JA, Bidali K, Weldele ML, Brown JL \& Holekamp KE 2008 Non-invasive measurement of fecal estrogens in the spotted hyena (Crocuta crocuta). General and Comparative Endocrinology 155 464-471. (https://doi.org/10.1016/j. ygcen.2007.08.002)

Wahaj SA, Place NJ, Weldele ML, Glickman SE \& Holekamp KE 2007 Siblicide in the spotted hyena: analysis with ultrasonic examination of wild and captive individuals. Behavioral Ecology 18 974-984. (https://doi.org/10.1093/beheco/arm076)

Watson M 1877 On the female generative organs of Hyaena crocuta. Proceeding of the Zoological Society of London 24 369-379.

Westphal U 1986 Steroid-protein interactions II. Monographs on Endocrinology 27 1-603. (https://doi.org/10.1007/978-3-642-82486-9_1)

Wilson A 2003 Sexing the hyena: intraspecies readings of the female phallus. Signs 28 755-790. (https://doi.org/10.1086/345320) https://joe.bioscientifica.com https://doi.org/10.1530/JOE-20-0252 (c) 2020 Society for Endocrinology Published by Bioscientifica Ltd. Printed in Great Britain 
Wilson JD, George FW \& Griffin JE 1981 The hormonal control of sexual development. Science 211 1278-1284. (https://doi.org/10.1126/ science.7010602)

Woodmansee KB, Zabel CJ, Glickman SE, Frank LG \& Keppel G 1991 Scent marking (pasting) in a colony of immature spotted hyenas (Crocuta crocuta): a developmental study. Journal of Comparative Psychology 105 10-14. (https://doi.org/10.1037/0735-7036.105.1.10)

Yalcinkaya TM, Siiteri PK, Vigne JL, Licht P, Pavgi S, Frank LG \& Glickman SE 1993 A mechanism for virilization of female spotted hyenas in utero. Science 260 1929-1931. (https://doi.org/10.1126/ science.8391165)

Yoerg SI 1991 Social feeding reverses learned flavor aversions in spotted hyenas (Crocuta crocuta). Journal of Comparative Psychology 105 185-189. (https://doi.org/10.1037/0735-7036.105.2.185)

Zabel CJ, Glickman SE, Frank LG, Woodmansee KB \& Keppel G 1992 Coalition formation in a colony of prepubertal spotted hyenas. In Coalitions and Alliances in Humans and Other Animals. Eds AH Harcourt \& FBM De Waal. Oxford, UK: Oxford University Press.

Received in final form 15 July 2020

Accepted 3 August 2020

Accepted Manuscript published online 4 August 2020 (c) 2020 Society for Endocrinology Published by Bioscientifica Ltd. Printed in Great Britain 